\title{
Knowledge production in a constructed field: reflections on comparative and international education
}

\author{
Bjorn H. Nordtveit
}

Received: 23 January 2015/Accepted: 29 January 2015/Published online: 13 February 2015

(C) Education Research Institute, Seoul National University, Seoul, Korea 2015

\begin{abstract}
Adopting Maria Manzon's theoretical framework, which draws on Foucault and proposes that comparative education as an academic field is socially constructed, I suggest that the field is neither stable nor well defined. To demonstrate this, I conduct a content analysis of the Comparative Education Review, using Klaus Krippendorff's methodological framework to study comparative and international education (CIE) researchers' understanding of the national-and of their related knowledge production in the field. Many comparativists express interests in multiple countries, and their knowledge production takes the form of individual country studies. The countries are habitually studied using a "problem approach" focusing on one specific aspect of the country under investigation and using an associated social science methodology deemed appropriate. Few comparativists are making explicit use of or reference to any methodology that is unique to comparative education. Efforts to catalog and systematize CIE research have demonstrated that the field is becoming so inclusive that it hardly is distinguishable from educational studies as a whole. Hence, I suggest that instead of speaking about unifying features of the field, it may be more relevant to speak about frequent elements, such as a focus on the national, and a knowledge production characterized by the academic practitioner who desires to improve the education systems studied. A third frequent element may be the
\end{abstract}

Paper presented at the 15th International Conference on Education Research (ICER) conference hosted by Seoul National University, South Korea, October 2014.

B. H. Nordtveit ( $\square)$

University of Massachusetts Amherst, Amherst, MA, USA

e-mail: bjorn@educ.umass.edu focus on educational development, thus justifying the label of "comparative, international, and development education." One challenge of the field is its dependence on Western social science discourses, which may be marginalizing other voices.

Keywords Comparative education - Comparative Education Review - Content analysis · Development . International education $\cdot$ Knowledge production

The light of the beginning envelops me.

Dimensions grow in 11-D.

Our distance can't be measured.

You won't notice it is relatively expanding.

I don't care about the theory. I just feel it.

A special event is happening here.

I don't care about the logic. I'm just feeling it.

(From the Japanese, Hatsune Miku song by ForgottenNobodyPrincess, 2009)

The super star Hatsune Miku (初音ミク) has since 2007 performed "live" in various places, including the Saitama Super Arena in Japan. She was the opening act for Lady Gaga's 2014 world tour (ArtRave: The Artpop Ball) and has huge numbers of fans following her all over the world. Under sponsorship from Louis Vuitton and with direction by Toshiki Okada, she performed the opera The End at the Théâtre du Châtélet in Paris in November 2013. According to Wikipedia, she was born on August 31, stands $158 \mathrm{~cm}$ tall and weights $42 \mathrm{~kg}$.

But who-or more specifically-what is Hatsune Miku? According to a CBS News headline, she is "The world's fakest pop star" (November 9, 2012). "Fake" is maybe not the most accurate term; a "constructed entity" may be more correct, as she is a Vocaloid, a singing synthesizer application. After launched, she became an instant hit: "With 
little else to go on, fans of the Vocaloid software made Miku their own, and the digital avatar quickly took off" (CBS News November 9, 2012). A Korean-based Vocaloid did not take long to follow the trend and launched Shiyu or "SeeU” (シュ).

I believe that there are certain commonalities between Hatsune Miku, Shiyu, and the field of comparative and international education (CIE). If one knows the basic terms of the CIE "software" language, one can quickly make it one's own, as long as it is somewhat related to some aspect of education somewhere. Often a country or nation-state lens is used for exploring this elsewhere (many "comparativists" are also studying their own education system). The nebulous field, like the popularity of Vocaloid's avatars, is expanding in an exponential way. The growing number of articles in the field is an example of its growing popularity: the 1959 Comparative Education Review's overview of "relevant" articles in the field contained reference to 18 articles; in 1960, it contained reference to 54 articles; in 1970, to 278 articles; in 1980 , to 460 articles; in 1990, to 606 articles; and in 2000, to 1,232 articles (Raby 2007). The latest bibliography of the field contained references to more than 2,500 articles (Easton 2014a, b). In other words, more and more knowledge production can be defined, in some way, as "belonging" to the field of comparative and/or international education.

Sometimes, these educational comparativists seem to adopt similar statements as in the Hatsune Miku song above, "I don't care about the theory. I just feel it;" and "I don't care about the logic. I'm just feeling it." On the one hand, the freedom of the field is so great that most educationalists can find their home in comparative and international education; on the other, the field risks to become so vague that it is almost impossible to define it, let alone describe its evolution. This has led certain authors to claim that there is "a yearning for convergence, for integration of content, for coherency" (Wolhuter 2008, 324).

To paraphrase the CBS quote above, this paper is a modest attempt to review how various fans of the CIE "brand" have made it their own and used it as a means to categorize their research. To do that, the paper is investigating two key issues in defining and understanding the field, that of the role of the national (or country level analysis) and how this national is studied, i.e., the knowledge production in comparative education. I will mainly be using the Comparative Education Review as a source to review how these two notions appear in CIE research, attempting to demonstrate that the field is shifting, expanding, and fluid.

I adopt Manzon's (2011) theoretical framework, which is drawing on Foucault, to demonstrate how comparative education as an academic field is largely "socially constructed" (Manzon 2011, 26), just like Hatsune Miku and Shiyu. Such definition largely repeals the idea of CIE as a "progressing" and "stable" science that "improves" over the years.

\section{Methodology}

To map aspects of the national and that of knowledge production the field of CIE, I conducted a content analysis of the Comparative Education Review (CER), mainly using Klaus Krippendorff's framework, as based on problemdriven analysis "motivated by epistemic questions" (2012, 355). The CER was founded in 1957 as the official journal of the US Comparative and International Education Society (CIES). Its aim, according to the Journal's web page, is to "advance knowledge and teaching in comparative education studies" as well as to investigate "the social, economic, and political forces that shape [education]" throughout the world. Content analysis relies on "ascertaining stable correlations with the research question" (Krippendorff 2012, 360 ), and as the $C E R$ may be seen as one of the important voices of US-based research in the field, I have considered it as a stable correlation with the research question, i.e., trends in situating the place of the national - and related knowledge production in CIE. This is also one of the limitations of the study; it does not include a wider review of other themes in CIE, nor does it investigate understanding of comparative education as related to other member societies of the World Council of Comparative Education (WCCES) and/or other publications, which would be of prime importance if my aim was to give a more global perspective of the field. I still believe that this review, even though modest in scope, may offer some ideas that concern the "larger" field of CIE.

The second part of Krippendorff's framework entails the location of relevant texts. I have used four ways to identify texts: (1) I have used JSTOR's CER search engine to trace manuscripts, using a set of keywords related to the theory and knowledge production of comparative education (such as field, evolution, history, methodology). (2) In addition, I have conducted an in-depth review of the first six volumes of the Journal (from 1957 through 1963), to trace initial conceptions of the field as related to these issues. (3) Also, I have used the 2013 and earlier bibliographies compiled by the CER together with accompanying bibliographic essays in an effort to trace some of the paths taken by research and publishing in the "larger" field of CIE (i.e., this time outside of the CER). The CER issues a yearly open access bibliography reviewing the previous year's research related to CIE: accordingly, the 2013 bibliography was published in August 2014. The yearly bibliography and its accompanying bibliographic essay (the last of which was published in November 2014) help track changes in the field of English language knowledge 
production in the field. For example, the 2013 bibliography contained references to 2,594 articles from 421 Journals (Easton 2014a). (4) Finally, every year, one article in the $C E R$ is given the Bereday prize. While the bestowal of the prize is not indicative of a trend, it is highlighting articles that are found to have a strong theoretical framework; innovative methodology; and a social utility and/or are contributing to the field in some other way-and therefore are considered as prominent "voices." The yearly bibliographies and bibliography essays, together with Bereday prizewinners, are therefore used in this paper as a proxy for analyzing some of the divergent streams manifested in CIE, as related to the national (or studies of "foreign countries") and to the knowledge production (methodologies) of the investigations. The limitation of the approach, as noted above, is its almost exclusive focus on English language knowledge production and the use of the CER (and this latter's yearly bibliography) as a proxy to better understand the field. Finally, I have also drawn on C. C. Wolhuter's (2008) excellent article "Review of the Review: constructing the identity of comparative education," reviewing and classifying the 1,157 articles that were published in the first fifty volumes (1957-2006) of the CER.

In terms of unitizing the texts (Krippendorff 2012), I usually refer to full sentences or paragraphs of the reviewed papers, to "contain" the authors' argument as much as possible. The coding includes nodes such as definition; field; trends; comparative education methodology; country; and national. For an analytic framework, I posit with Manzon that the field is composed of "historically contingent discursive formations of heterogeneous elements;" emerging from "power struggles" and constituting "power relations;" requiring "disciplines and disciplinary institutions" for "stabilization of discourses" (Manzon 2011, 28; emphasis in original). Following Manzon's (2011, 35) drawing on Bourdieu, I further contend that the various CIE discourses are "complex interactions ... that struggle to appropriate symbolic capital in the field, and the social, political and economic contexts in which these discourses are accepted or rejected." In referring to discursive struggles, if any kind stabilization of comparative education discourses can be found; it is in a first characteristic of paying attention to the national. This article will first review CIE's relationship and use of the "national" before turning to related conceptualizations of knowledge production in the field.

\section{Studies of "education in many lands"}

Comparative education is built on a long tradition of social exchanges; observation; and adventures. The historic stage of "adventure" has now in most cases been re-labeled and at present often consists of "study and research tours," or "field work," during which scholars are striving to understand the education systems of "the other." Comparison at the "country unit level" is at the heart of comparative education. Wolhuter, in his analysis of 1,157 articles appearing in the $C E R$ spanning its first 50 years, found that a constant and large majority of the articles were constituted of country case studies (varying between 66 and $87 \%$ of the total of articles published in the journal). ${ }^{1}$ This is not at odds with Cook, Hite and Epstein's (2004) mapping of characteristics of comparativists (in a survey of CIES members), finding that

Nearly one-third of respondents indicated they had no specific region that was foremost as a research interest but rather had multiregional interests. Of those indicating a single regional interest, about 23 percent listed Asia, 14 percent indicated Latin America, and slightly more than 13 percent listed Africa. Europe and North America (the United States and Canada) were represented by about 11 percent and 4.6 percent, respectively (p. 134).

The statistics indicate that many comparativists have interests in multiple countries, but that their knowledge production, in terms of studies, often takes the form of country studies (of individual countries). It also underlines the international interest of comparativists. Such approach has a long history and is connected to the initial conception of comparative education.

Comparative and international education in postwar United States first started as a subfield to educational studies with a formation phase heavily influenced by $\mathrm{Ge}-$ orge Z. F. Bereday. This latter was one of the initial champions of the field, widely considered "one of the greatest figures in modern comparative and international education" (Mei 2010). He was one of the founders of CIES and the initial editor of the Comparative Education Review between 1957 until 1966 (Altbach 1984). The "thing" of the "national" received early impetus in a time of cold war competition; one of the first activities of the CIES was to organize a study tour to the Soviet Union. In his editorial for $C E R$ Vol. 2(1), Bereday stated that "The Sputnik has unleashed a veritable storm of comparisons of American education with foreign education systems" and gave a number references to articles suggesting that "their" education system is "better than ours" or that such pretention would be a case of "mistaken envy" $(1958,1)$. The development of comparative education institutions is in many ways directly linked to the cold war:

\footnotetext{
${ }^{1}$ Divided into 5 -years periods, he found that $75 ; 76 ; 83 ; 78 ; 78 ; 82$; $87 ; 76 ; 78$; and $66 \%$ respectively of all articles were related to country studies.
} 
In November of that year [1956], Brickman convened a group of UNESCO and U.S. Office of Education intellectuals along with college teachers ... Their goal was to professionalize an endeavor that Brickman and his colleagues thought should distance itself from the instant expertise of those who were then organizing and profiting from tours behind the iron curtain in the name of "comparative education" and offering college credit for these junkets (Post 2006, x).

The first volumes of the Comparative Education Review give us some further ideas about the early understanding of the national. In the first issue of the Journal, Bereday introduced six textbooks in comparative education, four of which were focused on describing the national educational systems in countries that seem to have a claim to be examples of what was considered as "modern," such as England, France, the Soviet Union, and the United States. The last book, published in Manila, is an exception because it "deals with problems rather than with countries spanning areas such as India, Mexico, Hungary, Greece, Burma..." but also England, France, and Italy (1957a, 4). For this latter, although a problem-based approach is adopted, the "unit of analysis" is still the country level. Other articles discussed the advantages of an "area" approach as opposed to a "problem" approach in teaching comparative education and found that both had merits, albeit the latter "does not supply a general enough background of information about education and society in their totality" (Bereday 1958, 6).

Still, even though it was clear that most knowledge production in CIE focused on the national, it was (and still is) unclear on how to go about it. In another article in the first issue of the CER, Bereday (1957b) examined "methods in comparative education," making reference to 10 "major papers on the theory of comparative education" published between 1954 and 1957, but finding that "These papers could come to no very clear agreement as to what the delineations of the field are" (Bereday 1957b, 13). However, "in spite of the vagaries and indecisions" Bereday suggested these studies indicated that "all the existing contributions to comparative education could be classified into two types or branches: the area studies and the comparative studies" (ibid, p. 13). Despite the fact that the area studies (dealing with "education of one country"; p. 13; emphasis in original) are not comparative, they are nevertheless "not only legitimate but indispensable" in comparative education (p. 14). This is because "It is only on the basis of the extremely specialized and often painstaking work of the area scholars that a comparative student can attain the required breath of perception," which makes "the comparative branch of the discipline ... more complex and hence rare" (p. 14). This latter approach is also divided into two branches: the "total" approach and the "problem approach." Isaac Kandel is used as a reference for the total approach, dealing with "the totality of socio-educational systems," and "...freely shuttling from country to country, unhampered by the binding shackles of inadequate language, infrequent travel and scant training in academic disciplines" (p. 14). The problem approach, which was seen as "less ambitious," deals with one aspect of education and "traces its conditions under foreign conditions" (p. 14).

Yearly, CER bibliographies demonstrate that the national "problem approach" is still of prime importance in CIE, and perhaps increasingly so: "The proportion of regionally classified articles, which amounted to $56 \%$ of all references in 1979, $82 \%$ in 1989 and little more than half as great-but still 42 \%-in 1999 shrank even more markedly thereafter and was down to $7 \%$ this last year," whereas "articles focusing on levels and types of education have experienced the greatest proportional growth, from $6 \%$ in 1989 to a high of $53 \%$ in 2012 and $44 \%$ this last year" (Easton 2014a, 569). Within the latter category, we find that "the largest and most consistent numerical increase has been in Higher and Professional Education, Primary and Early Childhood Education, and Teacher Education and Training" (ibid, p. 569). However, a methodological question remains of whether these articles are not also national (or "regional") in nature:

Should an article on evolving language of instruction practices in Africa, for example, be classified under "Language Policy" or "Africa?" In fact, as noted below, one of the emerging criteria for selection of articles for the bibliography has been the framing of international education phenomena from a disciplinary perspective, which has in all likelihood inclined classification of borderline cases away from regional identification and into more thematic ones (Easton 2014a, 562).

Accordingly, whereas bibliographic indexes may appear to show certain "shifting" trends, it may be due to changing classification criteria rather than to a redefinition of the field. National "problem-based" studies still seem to be the "anchor" of CIE. Also, as of the nature of these "problems," Easton (2014a) note that the field is expanding. According to the aforementioned survey by Cook et al. (2004), which received "419 usable responses" ("representing 49 percent of the 853 accessible members;" p. 131), there are almost as many "problems" (or themes) in comparative education as there are comparativists:

Themes.-Our survey found few consensual answers within the society as to what themes are considered salient to the current state of comparative education. Globalization and gender, with each named by somewhat less than eight percent of respondents, were the top-listed clustered general themes, but 
clustered themes encompassed some 550 individual topics (p. 136).

The clearest characteristic of the field therefore seems to be a focus on a "problem" of education somewhere else, most often in a foreign country. As we have seen above, in reviewing the first volumes of the $C E R$, the country-specific focus of articles indicates that initial interests and expansion of the field was largely linked to the cold war. At the same time, with the liberation of colonies in the 1960s, a new field appeared, which incidentally also was related to the cold war: that of "development." We have seen above that CIE developed with the participation from "UNESCO and U.S. Office of Education intellectuals" (Post 2006), and it would thus be naturally linked to the emergent field of development. CIE would be intrinsically connected to the two aspects of the national: at one hand, a view of what "the others" are doing, in case it should be "better" than "us," and at the other side, promotion of a certain "modern" value system to "underdeveloped" countries (obviously, in the context of the cold war, such comparative education may also be promoting certain ideological values).

It should be noted that initially, comparative education was largely considered as a tool for teachers, and during the "formative period [1950s], considerable emphasis was placed on the teaching of comparative education in American colleges and universities and its use in the preparation of teachers" (Kazamias and Schwartz 1977, 154). However, as early as 1969 , W. J. Siffin in an article titled "The Social Sciences, Comparative Education, the Future, and All That" labeled the field as "the realm (s) designated as 'comparative, international, and development education"” (Siffin 1969, 252). In reviewing Bereday prize winners, these areas come clearly to the fore: The prize, initiated in 1980, demonstrates that a large majority of articles that are considered as being of "exceptional merit" are devoted to national and global issues of development. Prized pieces can largely be classified as:

- Development-related, national, e.g., "The Impact of Education on the Female Labor Force in Argentina and Paraguay" (Wainerman 1980).

- Development-related, global, e.g., "The Economics of Higher Education in Developing Countries" (Pscharopoulos 1982).

- Other, national, e.g., "Primer as Socializing Agents in American and Finnish Schools," (DiStefano et al. 1995).

- Other, global, e.g., "Globalization and International Student Mobility: A Network Analysis" (Shields 2013).

- Comparative education theory and methodology, e.g., "Ways of Knowing: Implications for Comparative Education” (Masemann 1990).

To a certain extent, these categories are representative of submissions to the Journal, and, according to the
Bibliographies (e.g., Raby 2003-2009; Easton 2014b), of knowledge production in the field. Wolhuter (2008, 329), in his analysis of CER articles, found that the focus of articles shifted according to the political issues at hand:

The most salient country in articles published in the first 15 volumes of the Review was the erstwhile USSR. This reflects the interest in the Soviet school system in the cold war era after the launching of Sputnik... In volumes 21-25, Greece was the focus of more articles than any other country. This was in the wake of the restoration of democracy and other widespread societal reforms in Greece... The USA moved into the top position in volumes $26-45$, which might be a reflection of the trend toward an inward orientation in the post-Vietnam years. In volumes 4650 South Africa attracted most attention, as interest grew in the post-1994 societal reconstruction project ...

Similar tendencies were found by Rust et al. (1999) in a study analyzing 1,969 articles published in three main journals of the field (Comparative Education Review from 1957 to 95; UK-based Comparative Education from 1964 to 95; and the International Journal of Educational Development from 1981 to 95): "The first major observation is that the geographic focus of comparative research has shifted dramatically from the 1960s until the present. In the 1960s, comparative education studies were largely focused on the developed world" (ibid, p. 103). It follows that the field is characterized, first by a country focus; second by a move toward a greater development focus, third, using Bereday's terminology, by analyzing countries using various "problem" themes. As noted above, this has led authors such as Siffin $(1969,252)$ to characterize the field as "comparative, international, and development education."

The question of whether comparative education is the same as international education and development education remains largely unanswered at a theoretical level (albeit frequently debated)_-but is implicitly considered the same by the Bibliographies. It sets up for questions related to unit and logic of comparative analysis (e.g., see Wilson 1994). According to Rust (2002), the distinction relates to the difference between the education practitioner ("international education") and the academic ("comparative education"):

...scholars typically regard "comparative education" to include the more academic, analytic, and scientific aspects of the field, while international education is related to cooperation, understanding, and exchange elements. International education is usually seen as a more practice-oriented activity, particularly in terms of cross-cultural and crossnational relationships. Its 
training orientation is to prepare men and women to participate in a world where international cooperation and understanding are essential (Rust 2002, iii).

A merger of these two "fields" took place in the period of 1969-1972 and was the results of "the debates at several annual Comparative Education Society (CES) conferences that eventually resulted in the marriage between comparative and international educators in 1969, formalized by the change in the name of our society from the CES to the CIES" (Wilson 1994, 450). ${ }^{2}$

Some scholars took the idea of the national and specifically the geographic even further. For example, Laadan Fletcher in 1974 took the viewpoint that comparative education, which he said was derogatively referred to as "education in many lands" (emphasis by author; $\mathrm{p}$. 352-353) lacked a methodology and ought to be linked to very clearly expressed guidelines. In view of the lack of focus and clarity of the field, he suggested that comparative education had a "geographical texture" and should rather cease to exist as comparative education and instead take up the label of geography of education:

One might ask why a geography of education is taught nowhere and suggest that if it were, the subject matter would not be distinguishable from what is at present designated as comparative education (p. 349). ...a change of name [from comparative education] to the geography of education [would] clarify the aims and purpose of the study (p. 353).

The suggestion of a change of name of the field does not seem to have gained a large supporter base, but demonstrates scholars' search of identity and a methodology for "their" field. As we have seen, instead of identity and focus, the most salient feature, then, of the field of CIE, is its focus on education "in many lands," using a thematic approach that is, as demonstrated by Cook et al. (2004), almost as diverse as the constituency of the field.

\section{Knowledge production: investigating the "other"}

Our initial analogy with Hatsune Miku gets into some trouble when discussing comparative education knowledge production. In order to write a Hatsune Miku song, one has to adopt a rather strict methodology in terms of software

\footnotetext{
${ }^{2}$ Rust (2002, iii) sets the date to 1972: "In 1972, under the leadership of its president, Stewart E. Fraser, the Society changed its name to the Comparative and International Education Society (CIES), and the intent was clearly to extend the boundaries of the field beyond comparative education to include international efforts in education."
}

use, which can then be used to tweak the music in the desired manner. In the field of CIE, there is no precise software language; as noted above, one only needs to possess a basic knowledge of any methodology. This does not preclude that there has been a search for specific methodologies of comparative education: Bereday, for example, described four key steps, including,

Description, Interpretation, Juxtaposition and Comparison, in which the last two stages mark the act of comparison. Comparison is seen as an ordering process, beginning with juxtaposition... (Edwards 1970, 241).

The "natural" starting point for this methodology could be interpreted to be the national or at least some geographic unity (locality; region; country...). Such understanding emphasizes the challenges mentioned above, in that the distinction between the practical (international education) and the theoretical (comparative education) is blurred. Kazamias and Schwartz $(1977,155)$, referring to Kandel's idealistic perspective, indicated a theoretical lens of comparative education "as a branch of the philosophy of education or as an inquiry into the history of ideas and "forms" in terms of its methodology and value." However, at the same time, they referred to the international and action-oriented perspective of CIE: "Kandel's moralism or "meliorism" stood in the way of dispassionate and objective, i.e., "scientific" analyses of school systems" (1977, 158).

From the beginning, there has been a search of cataloguing the methods used in comparative education and to define a "proper" comparative education methodology. One of the most well-known came in the form of the "Bray and Thomas cube" (1995), which described how units of analysis could be identified:

On the front face of the cube are seven geographic/ locational levels for comparison: world regions/continents, countries, states/provinces, districts, schools, classrooms, and individuals. The second dimension contains nonlocational demographic groups, including ethnic, age, religious, gender and other groups, and entire populations. The third dimension comprises aspects of education and of society, such as curriculum, teaching methods, finance, management structures, political change and labor markets. Many studies that are explicitly comparative engage all three dimensions, and thus can be mapped in the corresponding cells of the diagram (Bray et al. 2007, 8).

The cube brings Bereday's model further, with its front face representing the various dimension of the national-or the geographic units. The third dimension represents the "problem" to be studied, within the framework of a certain 
population (represented by the second dimension, which itself also could be geographic). Robert Arnove, in his 2001 CIES Presidential Address noted that the Bray and Thomas framework "recommends that comparativists contribute to improvements in theory and policy by introducing as many levels of analysis as possible to portray the complex interplay of different social forces and how individual and local units of analysis are embedded in multiple layered contexts" (p. 479). The effect of the "cube" was quite immediate. In a JSTOR search for CER articles using the cube in their keyword index, I found more than 30 references, ranging from "Nordic Countries" to Cambodia and Papa New Guinea. Also, methodological debates followed, based on the theoretical implications (and the possible expansion) of the cube. One possible implication and challenge is that comparative education became so inclusive that it could not be distinguished from educational studies as a whole. According to the cube, all research in education could be comparative: "Comparative Education is a wide field-some would say so wide and inclusive of so many issues in the study of education that the field's identity and boundaries are difficult to discern independently of the field of educational studies" (Mason and Katyal 2006, 1). It follows, of course, that all applicable methodologies in education could be used in the field of international and comparative education, or, as argued by David Post; "over the past 30 years, there have emerged multiple canons of research that are produced and -usually-mutually appreciated by the researchers and practitioners published by CER, including critical discourse analysis, ethnography, policy evaluation, historiography, national case studies, and crossnational or intranational hypothesis testing" (Post 2006, xii). Rust et al. $(1999,104)$ in their overview, found that comparative education contained every method used in social sciences and even some going beyond the realm of natural inquiry, such as "transcendental or cosmic" studies: ${ }^{3}$

There are (1) studies involving direct, concrete, and subjective experience with reality; (2) nominalistic studies based on specific times, proper names, and places; (3) studies deriving descriptive and historical generalizations; (4) nomothetic studies using common language; (5) studies based on mathematical models or theories; and (6) studies involving transcendental or cosmic conceptions.

As for "proper" comparative education methods, such as those developed by Bereday and others, Rust et al. (1999, 102) could find no trace: "Comparative education methodology, as reflected in the work of Bereday, Noah and

\footnotetext{
${ }^{3}$ I was curious about this latter, but could find no CER piece that employed "transcendental or cosmic conceptions."
}

Eckstein, Holmes, and other scholars, is not noted in the comparative studies." In searching for a unity of comparative education knowledge production, or at least some common occurrence (such as the focus on the national in a large percentage of studies), we should perhaps look at the purpose or intention of comparative education knowledge production. Arnove $(2001,480)$ suggested to "add the challenge of infusing philosophical, especially axiological, considerations in our work." In many cases, CIE has been seen as the field of the development "expert," and thus, a core function of its knowledge production is to "improve" other education systems. According to Wilson (1994), the "hybrid" product of the comparative and the international is that of the academic practitioner,

...who has been equipped with a viable academic understanding of comparative education and who has used that orientation to further the meliorative function common to both international and comparative education in his or her subsequent international activities (p. 450).

This notion of "expertise" has been underpinning the field and is largely exported to the countries targeted by comparativists. Brickman $(1977,398)$ even complained that such experts were somewhat absent in the creation of CIES: "the founding of the society might be regarded as an act of rashness perpetrated by a relatively younger generation rather than as the outcome of deliberation by the outstanding experts of the field." By introducing normative and practitioner aspects and "international activities," the field becomes triple, reflecting W. J. Siffin's 1969 characterization of the field and the examples given by Bereday prizewinners above, including comparative education, international education, and educational development.

The questions of axiological considerations and expertise obviously lead to the question of "which knowledge"? Since I posit that the field is constructed, such field-related expertise must also be constructed. As early as 1958, Kathryn G. Heath provocatively asked whether there is any specialized knowledge or methodologies in comparative education, while effectuating a cross-examination of the field: "A discipline defines its body of specialized knowledge. Have comparative educators defined their specialized body of knowledge? What is comparative education?" (p. 31). If there are no commonly accepted theoretic or methodological foundation of CIE, one must ask, with Cook et al. (2004), what comparativists are up to and which (various) theoretical frameworks they are using, especially since they are purportedly seeking to make education systems "better."

Connell (1983, vii) underlined that "The business of theory is to help us think clearly and see what is difficult to 
see. In social analysis, the forces and relationships we are trying to understand themselves create systematic obstacles to understanding." Likewise, one can argue that the business of comparative and international education is to help us "think clearly" about education in many lands. However, the uncertainty of knowing "which side is up" (Connell 1983), or what comparative education is, together with the confusion on the normative underpinnings of the field may be creating obstacles to our understanding. Connell (2007, vii-viii) "examines how modern social science embeds the viewpoints, perspectives, and problems of metropolitan society, while presenting itself as universal." Discourses taken from metropolitan and selfcategorized "global" knowledge production methods in social sciences are dominating the fields of international and comparative education and their associated theories of development. Constituents are, after all, building on the notion of a certain "expertise" in a field that has never been clearly defined and therefore largely will use social science methodologies to build legitimacy for their research. As noted by various studies, CIE debates have often concentrated on social, political, and economic "drivers" of education. ${ }^{4}$ Implementation and donor agencies have to justify educational projects in economic terms of effectiveness, resulting in debates and research that are in turn embraced by academia.

I believe that these relationships (between donors, implementers, and academia) result in a knowledge production that is to a large extent planned by-and often even geographically located in - the metropolitan North. Paul Feyerabend in Against Method, provocatively said that in the modernist viewpoint, "It does not matter who you are or when or where you are working; good science is good science and good science gives us good reason to believe in its results because its methods are the most rational" (in Gimbel 2011, 281). A modernist approach to research and knowledge production has caused some scholars, such as Linda Tuhiwai Smith, to characterize the term "research" as "probably one of the dirtiest words in the indigenous world's vocabulary" $(2012,1)$. I believe that comparative and international education practitioners may be in danger of construction of the "other" and of schools "in many lands," from a Northern theoretical lens, legitimated by the notions of "expertise" and "academic practitioner" as defined by Wilson (1994) above.

\footnotetext{
${ }^{4}$ For example, Cook et al. (2004), found, through classifying 550 different themes into 75 larger categories, that the following ten issues occurred most frequently: Globalization; Gender in education; Education and development; Equality in education; Multiculturalism, race, and ethnicity; Methodology/epistemology; Change and reform; Economics, microcredit, privatization; Funding/development; Policy/ politics/planning.
}

\section{Critique and discussion}

We then return full circle to the problem of Bereday. As Comparative and International Education is a socially constructed discipline, and its discourses are historically contingent, one almost always comes back to one basic question: what is comparative education? Cook et al. (2004, 147-148) elaborated on the question, wondering how a sense of continuity could be maintained in the field:

If comparative education then is a consequence of the political economy of knowledge production, such a perspective raises new challenges to the field: How can it maintain a sense of continuity within this dynamic of self consciousness and redefinition? How can a field that is incessantly re-creating itself appreciate and build upon collective advances and sustained lines of scholarship and inquiry? Are there any unifying trends, or does the wariness of institutional perspectives mean that reading lists and syllabi are recurrently turned over with each transient theoretical fad? If drawing boundaries is exclusionary by definition, how does the field evaluate the relative merits of that which should be included?

Cook et al. $(2004,149)$ came to no clear answer to these questions, but suggested that the field, by its own dynamism, "is alive and well and will undoubtedly remain so for the coming century," but also that "All fields must have boundaries, however porous, or it would be impossible to differentiate them one from the other. As R. F. Arnove, P. G. Altbach, and G. P. Kelly remind us, while comparative education remains a 'loosely bounded field,' it is 'held together by a fundamental belief that education can be improved and can serve to bring about change for the better in all nations'." The idea of the academic practitioner is implicit in this conclusion.

I suggest that instead of speaking about unifying features, it may be more relevant to speak about frequent elements found in CIE. Hence, I have suggested that the focus on the national (or some other geographic unit) is a feature adopted by a large number of comparativists (but by no means all comparativists), and that the knowledge production often is characterized by the academic practitioner who desire, in Wilson's terms "to further the meliorative function common to both international and comparative education" $(1994,450)$. A third frequent feature may be the focus on educational development, thus bringing the "hybrid" marriage between comparative and international education (Wilson 1994) to become "comparative, international, and development education" (Siffin 1969).

At the same time as most comparative and international education research and knowledge production have 
remained strictly embedded in a geographical focus, a number of scholars challenged it from the very start. Robert Ulich questioned, already in $C E R$ vol. 1, issue 2 (1957, p. 3), "do we really compare... or do we... merely juxtapose a more or less arbitrary number of individual data?" He continued:

But what is a "nation"? What is "national", especially in education? And is there something like a "national character"? Differences exist, no one will doubt. But are they due to "character", whatever that is, which is inherent in a nation's mental makeup, or are they but incidental, or perhaps merely accidental? (Ulich 1957, 4).

In 1986, as if attempting to answer Ulich's question, Gail P. Kelly and Philip G. Altbach suggested that a number of scholars already had started,

...challenge the use of the nation-state as the dominant category guiding comparative research. They argue that educational systems in one country are often affected more by factors outside that country than they are by factors inside it and urge research to focus on identifying these external forces (p. 91).

In particular, the use of dependency and World System theories was suggested to better understand how education evolved in any given educational system. Still, such analysis to a large extent sought to understand the national — through understanding global and "dependency" forces acting on such national systems. In addition, the questioning of the local and/or national came further to the fore, noting that globalization and hybridization are changing the landscapes of previously insular communities. Stephen Carney, in his writings - has been critical to the use of the national as basis for analysis and suggested that forces of globalization have changed the traditional "units" studied by scholars of comparative education (e.g., see Carney 2009). Also, Larsen and Beech (2014) suggested that,

...the field [of comparative education] should engage more thoroughly in theorizing about the concepts of space and place and, in particular, understand space not only as an object in its concrete form but also as sets of relations between individuals and groups ( $\mathrm{p}$. 191).

Various new methodologies and concepts are suggested as tools-adding incessantly to the very inclusive toolkit of comparative and international education (Larsen and Beech 2014; for example, demonstrate promising use of social network analysis for comparative education analysis).

However, at the same time as these critiques and new directions of study come to the fore, large-scale international assessments increasingly populate the field, measuring "quality" through the proxy of achievements on standardized tests. Increasing attention is given to the results of these tests (e.g., PISA, PIRLS, TIMSS). A large number of contributions to the $C E R$, for example, are based exclusively of analysis of these statistics, and makes Robert Ulich's 1957 question even more relevant "do we really compare... or do we... merely juxtapose a more or less arbitrary number of individual data?" As time passes, many comparative and international education scholars, in a quest of "serious" research, and sometimes in response to donor pressure, seem to adopt a "gold standard" randomized control trial (RCT) methodologies, using a nationalcentered research type-and an increasingly sophisticated "expert" language to "conduct" comparative education research and analysis "on" the other.

As an artificial field, we can understand comparative and international education by the players and outputs that populate the field. It may be seen as a field of "discursive struggle" that to a large extent has been played out in a metropolitan "global North." Comparative and international education may be seen as situated at the crossroads of conflicts between various discursive interests. CIE research may at times be in danger of focusing exclusively on the other without sufficiently taking into account the epistemologies of this other, and instead, is reconstructing him or her in a passive role as the studied. Using Edward Said's terms, the studied in comparative and international education sometimes "is given as fixed, stable, in need of investigation, in need even of knowledge of himself" (2007, 308). Hence, he or she is "re-invented" by the researcher, much in the same way as ForgottenNobodyPrincess invents songs that subsequently become a part of the cultural construct Hatsune Miku. To paraphrase Ulich (1957), we are trained at inventing the national and to find some "national character" in the educational system within the boundaries we study. If we cannot find - or prove - the national, we seek the local or the community-specific. Or we find a world system that can prove our position. Or we "globalize," seeking streams of influence; borrowing; adaptation; and imitation within systems. At the bottom of the cube, we find the individual, the foreigner-our final unit of investigation. Multiple voices-or discourses-are intertwined in these complex relationships, each seeking to appropriate symbolic capital or "visibility," often through research, publication, and policy-related work.

At the same time, in terms of knowledge production, using David Post's (2012) provocative term of "rank" scholarship, we note that a growing emphasis on Journal citation indexes exert increasing influence on the field, possibly forcing editorship decisions to be more strategic (looking for "quotable" papers). Similarly, new venues for publishing are opened through countless on-line options, 
including for fee and various open-source publishers (Easton 2014a). Pressure on pre-tenure faculty to publish also put strain on traditional venues and makes comparative education a "necessary field," just as for many of Bereday's colleagues, the Soviet Sputnik program was an impetus to study education in many lands.

Maybe, we should use Stephen Carney's quote from Cowen $(2003,301)$ stating that comparative education is a "display of a disciplinary form" and Carney's subsequent suggestion (Carney 2010, 125) that "at present this [comparative education] discipline 'form' accommodates the agendas of fishmongers, plumbers and florists, all of whom broadly agree on the ontological contours of the contemporary world." The relative flexibility of CIE is used by many scholars from diverse venues as a welcome opportunity to find an academic "home" and knowledge production outlet. Like the songs written for Hatsune Miku and Shiyu, the field is expanding and the sky seems to be the limit.

Kathryn G. Heath (1958) ended her article with the question of What is comparative education?, which, incidentally, was repeated by Erwin Epstein "commencing his presentation at the $11^{\text {th }}$ Comparative Education World Conference," at Chung'Buk in Korea in 2001 (Wolhuter 2008, 323), indicating that the question is perhaps still not answered, or, as it be, is answered in a great many ways. We can use the voices of Hatsune Miku and Laadan Fletcher (1974) and say that it is often, but not always, tales and histories that are made in a desire to improve education in many lands.

\section{References}

Altbach, P. G. (1984). Farewell to a founder. Comparative Education Review, 28(1), 5-7.

Arnove, R. F. (2001). Comparative and International Education Society (CIES) facing the twenty-first century: Challenges and contributions. Comparative Education Review, 45(4), 477-503.

Bereday, G. Z. F. (1957a). A note on textbooks in comparative education. Comparative Education Review, 1(1), 3-4.

Bereday, G. Z. F. (1957b). Some discussion on methods in comparative education. Comparative Education Review, 1(1), 13-15.

Bereday, G. Z. F. (1958). Some methods of teaching comparative education. Comparative Education Review, 1(3), 4-9.

Bray, M., Adamson, B., \& Mason, M. (Eds.). (2007). Comparative education research: Approaches and methods. CERC studies in comparative education (Vol. 32). Dordrecht: Springer.

Brickman, W. W. (1977). Comparative and International Education Society: An historical analysis. Comparative Education Review, 21(2/3), 396-404.

Carney, S. (2009). Negotiating policy in an age of globalization: Exploring educational "policyscapes" in Denmark, Nepal, and China. Comparative Education Review, 53(1), 63-88.

Carney, S. (2010). Reading the global. In Marianne Larsen (Ed.), New thinking in comparative education. Rotterdam: Sense.

Comparative Education Review Web site. Downloaded January 4, from: http://www.press.uchicago.edu/ucp/journals/journal/cer. html
Connell, R. W. (1983). Which way is up? Essays on sex, class and culture. Sydney: George Allen \& Unwin Pty.

Connell, R. (2007). Southern theory: The global dynamics of knowledge in social science. Cambridge: Polity Press.

Cook, B. J., Hite, S. J., \& Epstein, E. H. (2004). Discerning trends, contours, and boundaries in comparative education: A survey of comparativists and their literature. Comparative Education Review, 48(2), 123-149.

Cowen, R. (2003). Agendas of attention: A response to Ninnes and Burnett. Comparative Education, 39(3), 299-302.

DiStefano, C. D., Heurle, A., Huajaneu, H., Hyona, H., Lindeman, J., Neimi, P., \& Poskiparta, E. (1995). Primer as socializing agents in American and Finnish schools. Comparative Education Review, 39(3), 280-298.

Easton, P. (2014a). Documenting the evolution of the field: Reflections on the 2013 comparative education review bibliography. Comparative Education Review, 58(4), 555-574.

Easton, P. (2014b). Comparative and international education: A bibliography. Comparative Education Review, 58(S3), S1-S165.

Edwards, R. (1970). The dimensions of comparison, and of comparative education. Comparative Education Review, 14 (3), 239-254.

Feyerabend, P. (1993). Against method. In Gimbel, S. (Ed.), 2011. Exploring the scientific method. Chicago: University of Chicago Press.

Fletcher, L. (1974). Comparative education: A question of identity. Comparative Education Review, 18(3), 348-353.

ForgottenNobodyPrincess. (2009). Nebula. Downloaded on September 14, 2014. from: http://quizilla.teennick.com/lyrics/18135835/ nebula-romaji-a-english-lyrics-by-miku-hatsune-wowaka-vocal oid-song

Heath, K. G. (1958). Is comparative education a discipline? Comparative Education Review, 2(2), 31-32.

Kazamias A. M., \& Schwartz, K. (1977). Intellectual and ideological perspectives in comparative education: An interpretation. Comparative Education Review, 21(2/3), 153-176.

Kelly, G. P., \& Altbach, P. G. (1986). Comparative education: Challenge and response. Comparative Education Review, 30 (1), 89-107.

Krippendorff, K. (2012). Content analysis: An introduction to its methodology. Thousand Oaks: Sage.

Larsen, M. A., \& Beech, J. (2014). Spatial theorizing in comparative and international education research. Comparative Education Review, 58(2), 191-214.

Manzon, M. (2011). Comparative education: The construction of a field. Dordrecht: Springer.

Masemann, V. (1990). Ways of knowing: Implications for comparative education, Comparative Education Review, 34(4), 465473.

Mason, M., \& Katyal, K. (2006). Editorial: The many faces and functions of comparative education research in Asia. Comparative Education Bulletin, 9, 1-4.

Mei, A. (2010). George Z. F. Bereday (1920-1983) Short biography \& significant contribution. Singapore: National Institute of Education. Downloaded on October 6 from: http://www.nie.edu.sg/ research-publications/cieclopediaorg/cieclopediaorg

Post, D. (2006). Editorial. Comparative Education Review, 50(1), iiixii.

Post, D. (2012). Rank scholarship. Comparative Education Review, 56 (1), 1-17.

Pscharopoulos, G. (1982). The economics of higher education in developing countries. Comparative Education Review, 26 (2), 139-159.

Raby, R. L. (2007). Fifty years of comparative education review bibliographies: Reflections on the field. Comparative Education Review, 51(3), 379-398. 
Rust, V. D. (2002). The place of international education in the comparative education review. Comparative Education Review, 46(3), iii-iv.

Rust, V. D., Soumaré, A. Pescador, O., \& Shibuya, M. (1999). Research strategies in comparative education. Comparative Education Review, 43(1), 86-109.

Said, E. W. (2007). Orientalism. Twenty-fifth anniversary edition. London: Penguin Books.

Shields, R. (2013). Globalization and international student mobility: A network analysis. Comparative Education Review, 57(4), 609636

Siffin, W. J. (1969). The social sciences, comparative education, the future, and all that. Comparative Education Review, 13(3), 252259
Smith, L. T. (2012). Decolonizing methodologies: Research and indigenous peoples. London: Zed Books.

Ulich, R. (1957). The challenge of definitions in comparative education. Comparative Education Review, 1(2), 3-4.

Wainerman, C. H. (1980). The impact of education on the female labor force in Argentina and Paraguay. Comparative Education Review, 24(2 - Part 2), S180-S195.

Wilson, D. N. (1994). Comparative and international education: Fraternal or siamese twins? A preliminary genealogy of our twin fields. Comparative Education Review, 38(4), 449-486.

Wolhuter, C. C. (2008). Review of the review: Constructing the identity of comparative education. Research in Comparative and International Education, 3(4), 323-344. 